\title{
Intersecting Frames of Legibility in Conversion de Piritu (1690): A Remodeling of Paratexts in the Digital Setting
}

Roxana Sarion ${ }^{1}$

\section{Introduction}

The arrival of digital technologies has made it possible for scholars to access sources of information (maps, books and manuscripts) that would otherwise have remained unknown, forgotten or ignored on library shelves. In this chapter, digitalization stands for "the way in which many domains of social life are restructured around digital communication and media infrastructures,” and encloses the digitization material process “of converting individual analog streams of information into digital bits” (Kreiss and Brennen 1). The digitalization of institutional archives and private collections has led to a so-called democratization of access to historical materials by enlarging its audience to a broader circle of readers. The enhanced online digital exposure of texts written in the Americas has generated a significant body of scholarship in the last decades, focusing on texts produced in the period of colonial conquest and expansion. Open databases and online libraries, such as the John Carter Brown Library at Brown University, have contributed to unraveling the historical and cultural threads of Spanish American literature. ${ }^{2}$ The reframing of this literature within digital reading structures has led to the rediscovery of Spanish American literature in the twenty-first century. ${ }^{3}$

Importantly, the digital materialization of Spanish American colonial texts brings both benefits for and challenges to their readers. For example, paratextual elements take new

\footnotetext{
${ }^{1}$ I am grateful to the editors and reviewers for their insightful comments and suggestions for improvement. All disclaimers apply.

2 The John Carter Brown Library at Brown University holds one of the largest digital collections of maps and books written in Spanish America before 1820, with approximately 7,000 items. See: https://www.brown.edu/academics/libraries/john-carter-brown/jcb-online/digital-book-collections. The text I look at in this chapter belongs to this collection.

${ }^{3}$ Although the term "discovery" is ideologically charged, given its association with the Euro-Christian framing of Columbus' arrival to the Americas, in this chapter it refers to the revitalization and recontextualization of Spanish American colonial texts in the digital age.
} 
shapes and acquire different functions in a digital setting. Paratexts bind a text and determine its thresholds of interpretation (Genette 14), thereby guiding readers’ understanding through visual and textual elements that serve commercial, authoritative and navigational purposes. The reading scaffolds contained within the paratexts have the potential to increase readers' understanding of the communicative functions that underlie the "framing” or "packaging" of a text, and help them to discern broader patterns in a work's textual transmission (Peikola 45). In digital texts, paratextual elements interact and impact one another through hyperlinks, establishing connections that printed books cannot create (Birke and Christ 68). Moreover, digitalized reading structures transmute a diachronic (and often hierarchical) conception of Spanish American colonial literature into collections of horizontal, synchronic spatial images made accessible through navigating, surfing, linking and scrolling on the screen (Sanz and Romero 10).

In contrast to the openness that the digital format provides, a missionary text in the late seventeenth and early eighteenth centuries was both produced and received according to an established political and religious hierarchy in which writers, readers, editors, copy-scribes and commissioning patrons all played well-defined roles. Approaching texts of this type today requires not only asking how they were read by their contemporaries, but also what new meanings they unveil for current readerships.

This chapter will discuss the production and reception of Spanish American colonial texts in the light of the intersecting frames of legibility associated with their digitalization. Building on Genette’s (1987) foundational appraisal of paratexts and more recent work (Birke and Christ 2013; Peikola 2015), it focuses on the interpretative, authoritative and navigational functions endorsed by these frames or scaffolds of legibility. I will ask what problems present-day readers might face when reading digitalized colonial texts, how important it is to recreate the "original” colonial context when presenting digitalized 
historical narratives and whether the digitalization process changes the communicative situation between text and reader. Using samples from Conversion de Piritu, an understudied Spanish missionary text written in 1690 by the Franciscan missionary Matías Ruiz Blanco that was recently digitalized, I will first give a brief overview of the reading frameworks manifested in the form of paratexts, after which I will examine their interaction with hypertextual structures in the digital environment. I argue that the change from print to the digital format adds new cultural dimensions and layers of legibility to Ruiz Blanco’s text, enhancing its meaning-making capacity and opening it up to new audiences.

\section{Cultural Misreadings within a Colonial Setting}

From the moment Christopher Columbus set foot on land across the Atlantic Ocean in 1492, different worldviews have confronted and translated each other in continuing encounters between the so-called Old and New World. The textual production of Western and nonWestern modes of expression in the field of Spanish American literature is directly connected to a set of intricate social and political discourses grounded in violent and asymmetrical power relations between pre-Hispanic cultures and the Spaniards.

It was not until after the celebration of the 500th anniversary of the first “encounter/clash" between the two worlds in the Americas that many sixteenth- and seventeenth-century manuscripts were recovered and revitalized (Valdeón 153). Modern and contemporary readers find it challenging to grasp the world conveyed by the chronicles and missionary texts produced in the colonial period. One of the main obstacles is the fact that, in reading these texts, we cannot deal with one historical context, but have to consider multiple layers that need to be unfolded in order to convey the countless contesting histories of conquest and resilience hidden in the textual tissue. 
The digitalization of Spanish American colonial texts has increasingly interested scholars over the past decades. However, most of the studies (Mignolo 1994; Murray 1994) have focused on the analysis of texts written in Mexico and the Andes, while the missionary corpora from other regions, such as Venezuela, remain practically unknown. Conversion de Piritu (1690), a comprehensive missionary text written in the late seventeenth century by the Franciscan friar Matías Ruiz Blanco (1643-1705/1708?), stands out among the recently digitalized works that have been rescued from oblivion, with its digital availability serving as a valuable source to enrich and enlarge Spanish American historical and cultural studies in the twenty-first century. ${ }^{4}$

Conversion de Piritu tells the story of the conversion to Catholicism of the indigenous people located in the region of Piritu (on the present-day Northeastern coast of Venezuela), from the beginning of the conquest in the fifteenth century until the end of the seventeenth century. In 1690, under missionary commission, Matías Ruiz Blanco published the text, in which he sought to supply his fellow missionaries with cultural and linguistic tools to eradicate what he considered to be indigenous idolatry. Following the Council of Indies’ request for accounts of Northeastern Carib territories, he offered his own reading of indigenous practices and traditions in an encyclopedic report on the Carib world. Designed for evangelization purposes, the book was meant to serve as a manual for prospective Franciscan apprentices prior to their incorporation in the missions and during their conversion activities. Due to its instrumental purpose, the work has a hybrid structure consisting of four sections: I. a historical introduction, II. an account of the practice of teaching the Indians and a translation into the Cumanagot language of the Catholic Church’s

\footnotetext{
${ }^{4}$ The full title of this work is Conversion de Piritu de indios cumanagotos, palenques y otros, sus principios $y$ incrementos que hoy tiene con todas las cosas mas singulares del país, política y ritos de sus naturales, practica que se observa en su reducción y otras cosas dignas de memoria (Conversion of Piritu of Cumanagots, Palenques and other Indians, their principles and current growth, their most singular things, politics and rites, the practice observed in their reduction and other things worth remembering). For the sake of brevity, hereafter it will be referred to as Conversion de Piritu.
} 
essential sermons and sacraments, III. a grammar of the Cumanagot language, and IV. a Spanish-Cumanagot vocabulary.

In line with colonial missionary genre conventions, Ruiz Blanco performs in Conversion de Piritu an epistemological reconstruction of the New World through depictions of the Spaniards' encounters with the Carib people and approximations of ethnographic and anthropological aspects coexisting in the context of colonization. Therefore, he provides rich insights into indigenous cultural phenomena and conveys a historical account of the Carib languages and traditions. However, despite the fact that Ruiz Blanco vigorously defended indigenous political and social rights before the Spanish Crown, he could not escape the ideological and religious indoctrination frameworks he participated in. Thus, his account systematically measures indigenous practices and social structures against his own Christian standards and the seventeenth-century Western conceptualization of knowledge. The approach to the Other is performed from a Spanish Catholic standpoint that laid the foundations for Ruiz Blanco’s incomprehension of Carib indigenous traditions, perceived and rendered by him as pagan rites and idolatrous practices. This practice of cultural misreading is consistently present in the majority of Spanish missionary texts, including those by Bernardino de Sahagún, José de Acosta and others.

The asymmetrical power relations reflected by Ruiz Blanco in Conversion de Piritu attain new meanings for a readership in the context of the twenty-first century. Rather than considering Spanish American colonial texts from the traditional historical perspective, decolonial thinking (Mignolo 1995; Dussel 2003) analyzes them as dynamic loci of enunciation with symbolic, political and literary features in which colonized subjects are represented in subaltern positions in relation to their colonizers. Read within this theoretical framework, the protagonists of the text are no longer the dominant colonial agents (missionaries and colonizers), but the previously disregarded historical actors such as the 
indigenous (Carib) people. Decolonial readership navigates through Spanish American literature with the aim of dismantling colonial cultural and religious fallacies, encouraging thereby the recovery of extinct and endangered genuine indigenous narratives.

The three frames of legibility discussed in this section - namely the colonial, the postcolonial and the decolonial - converge in the digital version of the text by Ruiz Blanco, creating an intersection of plural meanings for audiences to actively engage with.

\section{Reframing the (Para)Text: From Printing to Digital}

Conversion de Piritu was published for the first time in Madrid in 1690 at Juan García Infanzón’s press (see Civezza 1879, 514-515; Viñaza 1892, 119; Streit 1924, vol. II, 643; Lejarza 1965, CX-CIX; Gómez Parente 1979, 443-444; Castro y Castro 1989, 469; Niederehe 1999, 253). Several exemplars of the original printed text have been preserved, although it is impossible to determine their exact number or location. ${ }^{5}$ Based on a recent search of the web and online catalogues, eleven exemplars have been identified in different libraries and private collections all over the world, a count that exceeds preceding records, which pointed to only two exemplars (Gómez Parente 426). ${ }^{6}$ In fact, Hispanic book historians faced serious issues in describing and locating the original text during the nineteenth and twentieth centuries. Its cataloguing resulted in confusing records, which persisted until the emergence of the digital copies in the twenty-first century. Not long ago, then, bibliographical information regarding Conversion de Piritu was scarce and confined to a small circle of scholars. This contrasts

\footnotetext{
${ }^{5}$ The editio princeps or first edition of a printed book is not unique. Although a particular exemplar may be the only known copy at a particular moment in time, another exemplar may later appear which bibliographers were unaware of: such exemplars may come from private collections, may have been hidden for various reasons, or may have been wrongly classified in public libraries, amongst other possibilities.

${ }^{6}$ Gómez Parente (1979) located two exemplars of the original printed text: one at the Bibliotheque Nationale du Paris and another at the British Museum in London (currently at the British Library). In addition, I have located nine more exemplars at the Biblioteca Nacional de Venezuela, the Biblioteca Nacional de España, the Bibliotheque Nationale du Paris, the Biblioteca Nacional de Chile, the Biblioteca de la Universidad de Complutense, the Biblioteca del Monasterio de Poblet, the Bryn Mawr collection and the John Carter Brown Library.
} 
with the open accessibility of the information currently contained in online databases and digital collections. The text itself is part of the e-book classic collection at the John Carter Brown Online Library and is treasured for its contribution to preserving valuable knowledge about early Carib colonial history.

In order to trace the different cultural and social appraisals that, through the centuries, have shaped the understanding of Conversion de Piritu, it is necessary to explore in more detail certain aspects of its materialization in print and in digital form. The materialization of a text, both as a physical object and as a data file, raises the question of its boundaries (Birke and Christ 68) and its frames of legibility. The functional aspects of paratexts are also subject to change depending on the format in which the book is presented to its readers.

Originally, Conversion de Piritu (1690) was printed in 8vo (or octavo) format, which, until the beginning of the nineteenth century, set serious literature apart from non-serious literature (Genette 18). Considered as a label of seriousness in the context of the printed book, the 8vo format placed the text in a favorable relation with its contemporary readers and ascribed it a privileged status of legibility. Currently, two copies of the original text of Conversion de Piritu are openly available online. One belongs to the digital library John Carter Brown, under the South American Indian collection, ${ }^{7}$ and the other to the National Library in Chile (Biblioteca Nacional de Chile). ${ }^{8}$ The copies are accessible in multiple layouts (ABBYY GZ, Daisy, EPUB, PDF, Kindle, Torrent, JP2 TAR, JP2 ZIP, etc.) with different degrees of readability. The meaning of format in the digital setting, which refers to a data file, supplants the dichotomy between serious and non-serious literature, but continues to act as an interpretative frame shaping the boundaries of a text's legibility in terms of accessibility and manageability.

\footnotetext{
${ }^{7}$ https://archive.org/details/conversiondepiri00ruiz.

${ }^{8}$ http://www.memoriachilena.cl/602/w3-article-10030.html.
} 
In addition to its first publication in 1690, the text was partially (re)printed on three occasions and all the resulting editions have been digitalized and made available online. Besides making the text visible and legible in a wide spectrum of formats, the digitalization of Conversion de Piritu allows readers to simultaneously access and compare its different versions, regardless of their physical location, thus bridging the temporal and spatial distance between them. The coexistence of the different editions of the text in the digital environment provides an overview of the evolution of its paratextual frames over time, revealing a profound change in its commercial, authoritative and navigational elements from the nineteenth century (when colonized countries started to fight for independence) to the twentieth century (with the rise of postcolonial theory) and the twenty-first century (with digitalization).

The coherence and logic of the reading frame is marked by those paratextual elements within (peritext) and outside (epitext) the text that mediate its message to the reader. According to Genette, the title and the front page belong to the publisher's peritext, the characteristics of which are spatial and material (16). Peritexts play a mainly commercial role in the dissemination of a text. In line with the legal requirements enforced by the Pragmatica de $1558,{ }^{9}$ the front page of Conversion de Píritu provides information regarding the content, the author, the authority the text obeys and the place of publication. These four constituent elements are presented in different rubrics separated by blank spaces and distinguished by the alternating use of uppercase and lowercase letters. The book’s main purpose is declared in the first lines of its front page, where Ruiz Blanco announces a description of the traditions, politics and rites of the indigenous people in the province of Píritu (Cumanagot, Palenques

\footnotetext{
${ }^{9}$ By the middle of the sixteenth century, the printing press had already become the best means to disseminate Protestant ideas in Northern Europe and, in order to avoid their spread in Spain, Phillip II adopted, on 7 September 1558, the Nueva orden que se ha de observar en la impresión de libros; y diligencias que deben practicar los libreros y Justicias, best known as the Pragmatica de 1558, a repressive legislation system through which the Spanish Crown took full control over the book trade and editorial production.
} 
and others), as well as a method to convert them to Christianity and "other things worth remembering.” The next rubric lists the author, Matías Ruiz Blanco, and his functions within the Franciscan Order: Lecturer of Theology, Examiner of the Diocese of Puerto Rico and Provincial Commissioner of the Missions of Píritu. The third rubric features the book’s dedication to the Marquis of Vélez, "worthy President of the Supreme and Royal Council of the Indies.” Lastly, separated from the other rubrics by a dividing line, the fourth rubric emphasizes that the book was printed “with grant” at Juan García Infanzón’s printing press in Madrid in $1690 .{ }^{10}$

The exhaustive detail provided on the front page of the first publication of Conversion de Piritu was notably reduced within the printing context of the nineteenth and twentieth centuries. The title, for instance, is transformed and adjusted to publishers' needs. Thus, in 1888, Julius Platzmann (1832-1902) published the last two sections of the 1690 text under the title Arte y tesoro de la lengua cumanagota (Grammar and dictionary of the Cumanagot language) ${ }^{11}$ as the third volume of Algunas obras raras en la lengua cumanagota (Some rare works in the Cumanagot language), a facsimile edition printed by B. G. Teubner in Leipzig. Another edition was published in 1892 by Victoriano Suarez in Madrid at Tomás Minuesa’s press with the title Conversión en Piritú (Colombia) de Indios Cumanagotos y Palenques, con la practica que se observa en la enseñanza de los naturales en lengua cumanagota por el P.Fr. Matías Ruiz Blanco de la orden de San Francisco seguido de Los Franciscanos en las Indias por Fr. Francisco Álvarez de Villanueva de la misma orden (Conversion in Piritú (Colombia) of Cumanagot and Palenque Indians, with the practice that is observed in their

\footnotetext{
10 "With grant" (cum privilegio) refers to the Spanish Crown’s censorship power over the press in Early Modern times, when the King granted upon request and payment of a fee by the interested party (author, bookseller, etc.) the exclusivity on the benefits of printing and selling of a book for a ten-year period.

${ }^{11}$ In the Spanish American context, "arte" (Lat. ars) or grammar was the term used to designate a set of linguistic rules and norms that define a language. "Tesoro" (Lat. thesaurus verborum) was used for bilingual or multilingual lexicographic studies having the indigenous languages as departing languages (L1) and Spanish as the targeted language (L2).
} 
instruction in the Cumanagot language by P.Fr. Matías Ruiz Blanco of the Franciscan order followed by the Franciscans in the Indies by Fr. Francisco Álvarez de Villanueva of the same order). This edition contained only the first two sections of the text from 1690 and was included in tome seven of the series Colección de libros raros y curiosos que tratan de América (Collection of rare and curious books dealing with the Americas). In 1965, the National Academy of History in Venezuela published an edition of the text in Caracas with the short title Conversion de Piritu, which was included, together with a Tratado histórico [y Diario] (Historical treatise [and diary]) by Friar Ramón Bueno, in the collection Fuentes para la historia colonial (Sources for colonial history). This edition focused on the historical account and included solely the first section of the 1690 text with a preliminary study by Fidel de Lejarza.

As this makes clear, the original text was never printed in its original format again and became subject to significant changes depending on publishers' interests in all successive editions. In the nineteenth century, the first or the last two sections were included in anthologies of "singular" and "rare” works (obras raras, curiosas), together with other missionary texts on the Cumanagot language. In the twentieth century, the text was again partially reprinted and acknowledged by the Venezuelan National Academy of History as one of the primary sources of colonial history.

It was in the twenty-first century that the original text of Conversion de Píritu (1690) re-emerged with its full title and internal structure. Digital practices have had a deep impact on the production and dissemination of Conversion de Piritu (1690) by replacing the printed book with electronic files and enabling the readership not only to access it as a whole again, but also to create a dialogue between its successive editions. Seen as modes of thinking, the dissemination practices in the digital setting promote the exchange of knowledge in interactive networks. The hypertext serves as an ideal medium for collating and presenting 
the textual variants that led, over time, to the establishment of Conversion de Piritu as an authoritative text.

Spanish American colonial texts were often written on demand, directly endorsed by political and religious interests, and printed only after several censors had authorized their publication, thus hierarchically determining their production and reception. Licenses and dedications are paratextual elements that validate a certain authority and guide readers towards a specific understanding of a text. Conversion de Piritu had, as reflected in its paratexts, an official nature. Two licenses, namely of the "order” and of the "ordinary” (ecclesiastical and civil), together with two additional civil censorships, provided a clear frame of legibility, underlining the institutional interdependency between the missionary enterprise and the Spanish Crown during the colonial period: Licensed by friar Julian Gumillas (General Commissioner of Indies); Censorshiped by friar Damian Cornejo (General chronicler of the order); Licensed by Alonso Portillo y Cardos (Vicar of Madrid) and Censorshiped by Francisco de Ayeta (Franciscan Counselor of the West Indies).

Furthermore, Ruiz Blanco dedicated his text to the Marquis of Velez, a major figure in the governmental, administrative and military authority of the Supreme Royal Council of the Indies at the time, paying respect to his patron and justifying his work as useful for the conversion to Catholicism of colonized subjects in the New World. Generally, a dedication identifies the type of relationship between the author and the person addressed, whether intellectual or personal, actual or symbolic (Genette 135). Dedications in the colonial context had a moral, intellectual or economic function, and were commonly addressed to the King. Currently, they have largely lost association with patronage, so that moral, intellectual or aesthetic functions prevail. In the digital context, the authoritative function of the paratexts is lessened, although they can still guide the readers in reconstructing the religious and political hierarchy that governed the publication and reception of Conversion de Piritu in 1690. 
In the digital environment, Conversion de Piritu's authoritative paratexts acquire new discursive functions beyond their historical context, since the religious and political forces at the time of publishing are no longer active in the present reading frame. Now the authoritative function of the text is determined by the cataloguing criteria and cultural meanings used and assigned by institutions such as public and private libraries and collections, which acknowledge Conversion de Piritu as an important part of the preHispanic Carib heritage. The reading process occurs at the intersection of the reader, the text, and collective and private online databases that address wider audiences and activate new reading frames. This plurality of readings converges in a virtually unified system of knowledge, while at the same time the limits of the text are expanded to a hypertextuality that allows private and collective dissemination practices to enter into a cultural exchange.

Moreover, former authority schemes are re-contextualized and multiplied by the digital readership. The audience of Conversion de Piritu is now considerably larger than in the seventeenth century and comprises readers from a broad spectrum of disciplines (historians, anthropologists, theologians, literary theorists, linguists, etc.). In the digital landscape, readers themselves become "authorial" and are able to intervene in the communicative situation with a certain degree of authority (Birke and Chris 71). Via userfriendly interfaces, readers can access the documentary sources located in digital collections, allowing them to perform extensive readings and comparisons between the different versions of the text and critical standpoints, thereby creating a multidisciplinary conversation that enriches the text's meaning-making potential.

In the traditional print format of Conversion de Piritu, the reader interacts with a single text, applying linear strategies to construct its meaning. Thus, following a guidebook’s convention, Ruiz Blanco systematizes the search through his text based on thematic criteria, as indicated in the table of contents. The distribution of contents is meant to facilitate the 
selective reading of the different chapters and is displayed in alphabetical order with a precise indication of the numbering of folios and paragraphs. In fact, the book contains two tables of contents. The first one is an index that refers to the contents of the two first sections of the book (the historical treatise and the account of the practice of teaching the Indians). The second one corresponds to the third section of the book (the Cumanagot grammar) and follows an organizational criterion based on morphological categories with consecutive page numbering.

Tables of contents and indexes have a meaningful navigational function in that they guide the reader's reception in a more structural sense, both when approaching the text and when orienting within the text (Birke and Chris 68). Although Genette labeled them as "no more than a device for reminding us of the titular apparatus” (316), these paratexts become more relevant in the digital context, where reading and understanding commence with a keyword typed into a search field or web engine.

Translated to the digital environment, the original tables of contents and index are mentioned in the metatext accompanying the digitalized text in the webpage contents. Thus, different levels of proximity between a text and its paratexts are established. The navigational functions now expand to a hypertextual dimension in which readers can access new features inaccessible in the printed format. For instance, in the online version of the text, computational linguistics allows the reader to discover the spatial incidence of keywords through a search tool that returns a mapping bar with icons that connect directly with the page numbering of the printed text.

The online context, moreover, offers several downloadable formats of the printed text, in addition to links to other web sources on related topics such as the book's author, title or tables of contents. The metadata available online enable the reader to actively interact with the text and other relevant web contents endorsed and labeled with keywords: Franciscans, 
Cumana Indians, Palenque Indians, Cumana language, Indian linguistics, Imprint 1690. Thus, the online reading opens up manifold possibilities to expand its reading process, which does not necessarily stop when targeted information has been located, but can go further through links and correlated metadata. ${ }^{12}$ It creates new forms of cultural interchange by linking the primary text to a corpus - bounded and stored with other bodies of knowledge - such as online databases or encyclopedias.

The degree to which the web navigation expresses an interpretative function depends on the reader. In the digital version of Conversion de Piritu, the reader cannot only see the text in its linear form but also make use of several search options that enhance its manageability. There is, then, a substantial difference between the printed book and its digital materialization in terms of legibility. This difference lies mainly in the way the online environment enables the reader to manipulate the text and in the layers of annotation available online, which far exceed the possibilities of a physical book. While this diminishes the degree to which the (para)textual elements can guide the text's interpretation, navigating through the hypertextual reading structure can be far more complex and demanding than perusing the traditional table of contents or indexes. In short, the digital frame creates a system of meta-reading that transcends the printed text with its fixed boundaries, places and roles, and projects a wider web of knowledge taking the text’s readership "beyond the book.”

\section{Final Remarks}

Technology has changed the way readers understand texts originally designed for printing. This chapter has exposed how the digital materialization of a Spanish colonial text remodels its paratextual boundaries over time and space. Conversion de Piritu (1690) has served as an

\footnotetext{
12 The numerous types of links that e-books and their delivery devices offer raise the question of whether these should be considered part of the text, paratextual elements or something entirely beyond the text.
} 
example to demonstrate how intersecting frames of legibility in the digital environment affect the communicative situation and add new cultural dimensions to the text's reception.

Thanks to the digitalization process, the original version of Conversion de Piritu is not only available to present-day readerships, but also interacts with its subsequent similarly digitalized - editions in a hypertextual system. The open accessibility granted by the digital environment creates both challenges to and benefits for the text's thresholds of interpretation, as reflected in its paratextual functions. In terms of benefits, digitalization enacts the text's preservation and audience development by enhancing its visibility and manageability. Nevertheless, digitalization can be problematic when the text appears hastily copied and partially reproduced or incomplete, making the reading process difficult. In addition, the reader may lose the original notion of format, which assigned an added cultural value to the text.

Building on Genette's theory, the commercial (title and front-page), authoritative (licenses and dedication) and navigational (table of contents) functions contained in the paratexts have been analyzed in terms of their variant forms in the printed and digital formats of Ruiz Blanco’s work. I have shown how the original text became the subject of significant changes over time as a result of publishers’ divergent commercial interests. Currently, various cultural institutions assume an authoritative function in the dissemination of Conversion de Piritu (1690) by cataloguing it as part of their most valuable collections of Spanish American colonial literature. Being addressed to wider audiences, however, has multiplied the authorial and authoritative schemes influencing its interpretation, giving the reader, in the digital environment, more control over how the text is read.

\section{Works Cited}

Birke, Dorothee, and Birte Christ. "Paratext and Digitized Narrative: Mapping the Field.” 
Narrative 21.1 (2013): 65-87.

Castro y Castro, Manuel. “Lenguas indígenas transmitidas por los franciscanos del S. XVII.” Actas del III Congreso Internacional sobre los Franciscanos en el Nuevo Mundo (Siglo XVII). La Rábida, 18-23 September 1989. 431-72.

Civezza, Marcelino da. Saggio di bibliografía geográfica storica etnográfica sanfrancescana. Ranieri Guasti, Prato, 1879.

Cho, Byeong-Young, and Afflerbach, Peter. “An evolving Perspective of Constructively Responsive Reading Comprehension Strategies in Multilayered Digital Text Environments.” Handbook of Research on Reading Comprehension. Second Edition. Ed. Susan E. Israel. New York: Guilford Publications, 2016. 109-35.

Dussel, Enrique. “Europa, modernidad y eurocentrismo.” La colonialidad del saber: eurocentrismo y ciencias sociales. Ed. Edgardo Lander. Buenos Aires: CLACSOUNESCO, 2003. 41-53.

Genette, Gérard. Paratexts: Thresholds of Interpretation. Trans. Jane E. Lewin. Cambridge: Cambridge UP, 1997.

Gómez Parente, Odilio. Labor Franciscana en Venezuela. Tomo I. Promoción indígena. Caracas: UCAB, Instituto de investigaciones históricas, Centro de lenguas indígenas, 1979.

Kreiss, Daniel, and Scott Brennen. "Digitalization and Digitization.” culturedigitally.org. Culture Digitally, 8 Sept. 2014. Web. 15 Dec. 2017.

Lejarza de, Fidel. Estudio preliminar en Conversión de Píritu del P. Matias Ruiz Blanco, O.F.M y Tratado histórico del P. Ramón Bueno, O.F.M. Caracas: Fuentes para la historia colonial, 1965.

Mignolo, Walter. Local Histories/Global Designs: Coloniality, Subaltern Knowledges and Border Thinking. Princeton: Princeton UP, 1994. 
The Darker Side of the Renaissance: Literacy, Territoriality, and Colonization. Ann Arbor: U of Michigan P, 1995.

Murray, James C. Spanish Chronicles of the Indies: Sixteenth Century. New York: Twayne Publishers, 1994.

Niederehe, Hans-Joseph. Bibliografía cronológica de lingüística, la gramática y la lexicografía del español (Bicres) 2: Desde el año 1601 hasta el año 1700. Amsterdam: John Benjamins, 1999.

Peikola, Matti. "Manuscript Paratexts in the Making: British Library MS 6333 as a Liturgical Compilation.” Discovering the Riches of the Word. Ed. S. Corbellini, B. Ramakers and M. Hoogvliet. Leiden: Brill, 2015. 44-67.

Ruiz Blanco, Matías. Conversion de Piritu de indios cumanagotos, palenques, y otros: sus principios, y incrementos que oy tiene, con todas las cosas mas singulares del pais, politica, y ritos de sus naturales, practica que se observa en su reduccion, y otras cosas dignas de memoria. Madrid: Juan Garcia Infançon, 1690.

Sanz, Amelia, and Dolores Romero. Literatures in the Digital Era: Theory and Praxis. Newcastle: Cambridge Scholars Publishing, 2007.

Streit, Robert. Bibliotheca missionum, vol. I, II, III. Aachen: Xaverius, 1924-27.

Valdeón, Roberto A. Translation and the Spanish Empire in the Americas. Amsterdam: John Benjamins, 2014.

Viñaza, Cipriano Muñoz y Manzano. Bibliografía española de lenguas indígenas de América. Madrid: Sucesores de Rivadeneyra, 1892. 
